\title{
LOS PATRONES 'WORLD CULTURAL': INEQUIDADES EN LA EDUCACIÓN SUPERIOR Y LAS ACCIONES AFIRMATIVAS EN BRASIL.
}

Resumen. Este artículo discute la reciente introducción de cuotas para minoridades étnicas en las Universidades de Brasil bajo una perspectiva teórica diferente. En Brasil fueron adoptadas recientemente las políticas destinadas a disminuir las disparidades existentes en la participación a la educación superior por parte de los brasileros descendientes de africanos. Sin embargo la categoría "minoría étnica" es una categoría que para la auto percepción de los brasileros resulta poco clara, lo que provoca que dicha política tenga muchas desventajas para apoyar el acceso a la educación - en particular - y combatir la exclusión social en general, clase o raza. Considerando una directriz teórica relacionada a la globalización en general y particularmente a la teoría neo-institucional de 'world polity', el artículo sugiere considerar la adopción de las acciones afirmativas en las Universidades de Brasil como ejemplo del proceso de difusión de ideas y conceptos globales - o 'world cultural' - para lo nivel nacional. Como muestra la breve discusión de la implementación de las políticas afirmativas, questiones estructurales son tratadas solo marginalmente.

Palabras claves: Brasil, investigación del mundo político, educación universitaria, acciones afirmativas.

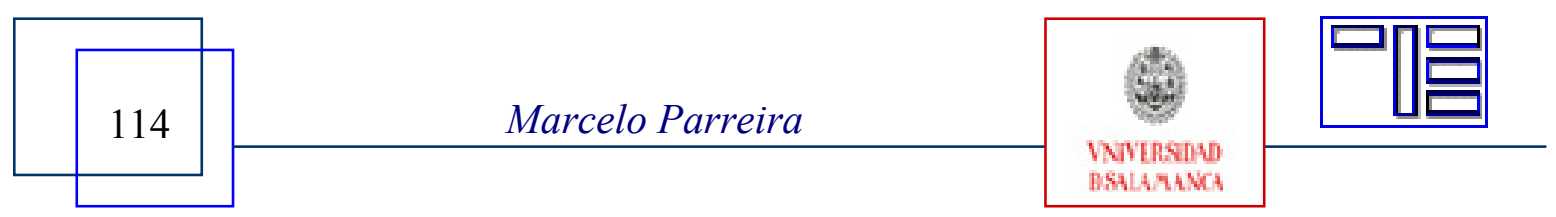




\section{WORLD CULTURAL PATTERNS: INEQUITIES IN HIGHER EDUCATION AND AFFIRMATIVE ACTION IN BRAZIL}

Abstract. This contribution discusses the introduction of quotas for ethnic minorities in Brazilian universities under a rather different theoretical perspective. In Brazil these policies have been recently adopted as a means of diminishing the disparities in higher education entrance for Brazilians of African descent. Since the category 'ethnic minority' seems at odds with the Brazilian self-perception, these policies have triggered an interesting controversy over what categories to use when tackling disadvantages in access to education in particular and social exclusion in general, e. g. class or race. In line with globalization theory in general and particularly with the neoinstitutionalist world polity-research this article suggests to view Brazil's adoption of affirmative action in university entrance processes as one instance of the diffusion of global - or world cultural - ideas and concepts to the national level. As the brief discussion of the implementation shows structural issues are only partly addressed in Brazil.

Key words: Brazil, world polity research, higher education, affirmative action.

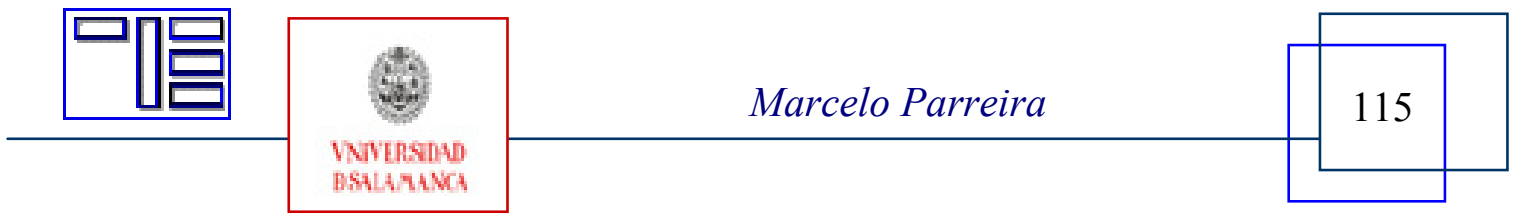


Revista Electrónica Teoría de la Educación.

Educación y Cultura en la Sociedad de la Información.

http://www.usal.es/teoriaeducacion

Vol. 9. No 2. Mayo 2008

\section{MODÈLES DE LA WORLD CULTURE: INÉGALITES DANS L'ENSEIGNEMENT SUPERIEUR ET DISCRIMINATION POSITIVE AU BRÉSIL}

Sommaire. Cet article discute l'introduction de quotas pour des minorités ethniques dans les universités au Brésil en se fondant sur une perspective théorétique différente. $\mathrm{Au}$ Brésil, ces politiques de discrimination positive ont été adoptées afin d'amoindrir les disparités d'accès à l'enseignement supérieur pour les brésiliens de descendance africaine. Étant donné que la catégorie 'minorité ethnique' ne corrèle pas avec l'autoreprésentation des brésiliens, ces politiques ont initié une controverse intéressante au sujet de quelles catégories sont utiles en remédiant à des inégalités d'accès à l'éducation en particulier et l'exclusion sociale en général. Alignés aux théories de la globalisation en général et particulièrement à la théorie néoinstitutionaliste du world polity, cet article suggère comprendre l'adoption brésilienne des quotas comme un exemple de la diffusion des idées et concepts globaux - ou world cultural - au plan national. Comme la brêve discussion du procès d'implémentation révèle, des questions structurales ne sont pas abordées.

Mots - clés: Brésil, world polity, recherche, enseignemnt supérieur, discrimantion positive.

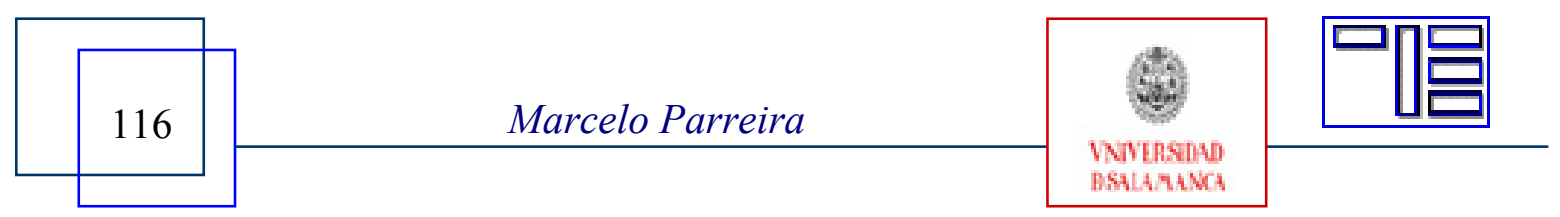




\begin{tabular}{|c|c|c|}
\hline \multirow[t]{2}{*}{ ص包 } & \multicolumn{2}{|c|}{$\begin{array}{l}\text { Revista Electrónica Teoría de la Educación. } \\
\text { Educación y Cultura en la Sociedad de la Información. }\end{array}$} \\
\hline & http://www.usal.es/teoriaeducacion & Vol. 9. $N^{o}$ 2. Mayo 2008 \\
\hline
\end{tabular}

\title{
WORLD CULTURAL PATTERNS: INEQUITIES IN HIGHER EDUCATION AND AFFIRMATIVE ACTION IN BRAZIL
}

\author{
Marcelo Parreira do Amaral \\ marcelo.parreira@uni-tuebingen.de \\ Universidad de Tübingen (Alemania).
}

\section{1.- INTRODUCTION.}

Globalizing processes have not only speeded up transnational economic and cultural processes, they have also caused the aggravation of social disparities, inequities, and the risk of 'falling' throughout the world. Publications of all sorts have helped create an awareness of these phenomena as global problems (see only Bourdieu et al., 1999; Luhmann, 1999, 2005; Le Monde, 2003). Has the consciousness of these social problems been globalized, so have also the understandings of the phenomena as well as concepts of means to cope with them. Examples can be drawn from several fields, but especially from social policy. The debate around 'social exclusion' is such an instance in which awareness, terminology, and assumptions about its 'remedies' have been circulated globally; especially but not only in Europe one observes the convergence of the different nationally bound discourses and contexts around this formula. This process has been decisively been influenced by international actors such as the European Union (cf. Commission of the European Communities, 1993; Atkinson/Davoudi, 2000; Kronauer, 2002), the OECD (cf. the series 'The Battle against Exclusion').

A further instance of such globalizing processes can be observed in the multiculturalism discourse (Glazer, 1997). Multiculturalism is perceived as a means to guarantee social cohesion through the idea of unity through the recognition of diversity, implying not only the right to be different but also the right to equal opportunities, hence the argument for preferential treatment. Even though one has to acknowledge that they do not necessarily mean the same; Glazer argues: "Quotas [...] are not multiculturalism. Affirmative action has nothing to do with the recognition of cultures [...]." $(1997,12)$. And it is on how to arrange this latter issue that opinions generally diverge. One of the most debated concepts refers to the preferential treatment of a underprivileged group, generally associated with the US-American policy of affirmative action (Ooiman Robinson, 2006) even though the concept originates from India where it should compensate for the disadvantages of the Dalit caste (commonly known as 'Untouchables') (Deshpande 2006).

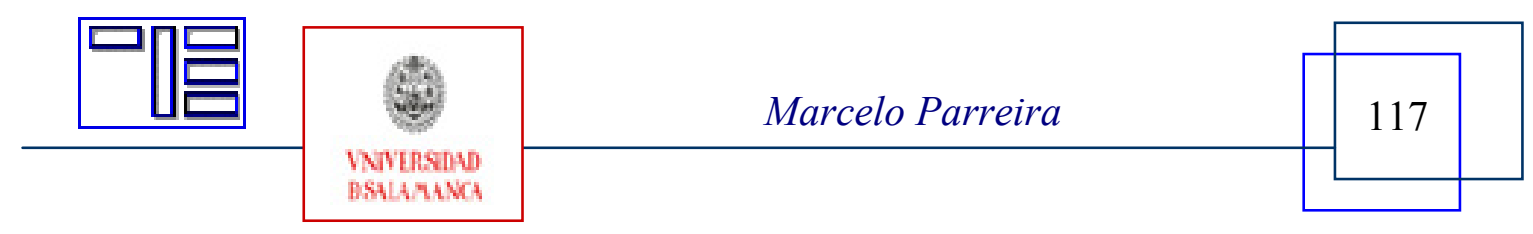


Revista Electrónica Teoría de la Educación.

Educación y Cultura en la Sociedad de la Información.

http://www.usal.es/teoriaeducacion

Vol. 9. No 2. Mayo 2008

A very recent example can be seen in Brazil, where affirmative action policies have been recently adopted as a means of diminishing the disparities in higher education entrance for Brazilians of African descent.

The examples mentioned above share at least three similarities: they are social problems present in all modern societies regardless of their level of development; the debates around them have been heavily influenced by global understandings of stateof-affairs and can be regarded as 'institutionalized rules' (Meyer/Rowan, 1977, 341), i. e. taken for granted as the most sensible way to organize things; finally, international actors have been substantially involved in their diffusion worldwide. There are different perspectives on how to conceive of this cultural-cognitive influence on public policies and on the ways of diffusion. For instance, Pierre Bourdieu and Loic Wacquant (1998) conceived of these diffusion processes as (USAmerican) 'cultural imperialism' and attributed its capacity to 'universalize the North American doxa' to the modes of functioning of international organizations, transnational academic networks, global scale publishing houses, or through funding agencies such as the Ford or Rockefeller Foundations. While this interpretive model seems to account for part of the reality in Brazil, it leaves important issues untouched by focusing solely on rational aspects. In this contribution I rather adopt a world polity perspective (see below) and argue for the interpretation of the Brazilian case as an instance of the diffusion of world cultural ideas and concepts (world polity principles) to the national level. From this perspective the perceived structural homology (isomorphism) is nothing but self-evident since the legal structures and practices of nation-states have become more similar, esp. in fields such as human rights or ecology. An understanding of the adoption of quotas for Afro-Brazilians in higher education entrance processes in line with the world polity research calls attention to apparently non-rational characteristics of the debate as well as to the actors involved in it. It allows furthermore an insight into what can be termed localization of the global while at the same time paying enough attention to the different ways of coping with global influence on the national dimension. Against this background, structural aspects of the issue can be reformulated and discussed.

The next section presents the central concepts, arguments, and a few results of the empirical studies wrought by the world polity research. In a second step, the background of the Brazilian of the discourse and of the actual implementation process of affirmative action in universities is unfolded. The final section discusses some issues from the world polity perspective and addresses some implications.

\section{2.- WORLD POLITY RESEARCH.}

Among recent discussions on globalization and world society in the social sciences one particular theoretical strand stands out prominently for it conceptualizes the cultural frame larger than nation-states, i. e., it puts forward a world cultural frame.

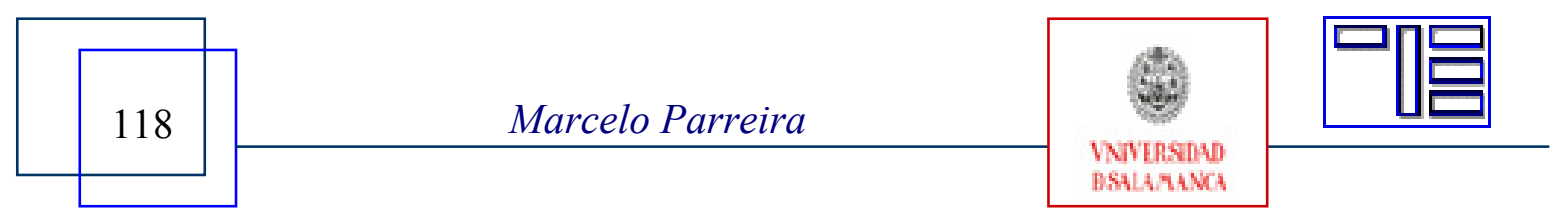


The neoinstitutionalist world polity research has been developed by a group of scholars around John W. Meyer at Stanford University since the 1970s.

'World polity' is understood by the neoinstitutionalists in a manner different from political scientists, who rather use the term to denote the institutional aspects of a territorially defined political system (e. g. a nation-state) (Krücken, 2006, 139f.). The neoinstitutionalist usage, rather, draws attention to institutional factors on a (transnational) global dimension. The world polity research is seen as a macrosociological approach and opposes the micro-sociological and 'realist' direction dominant especially in the American social sciences in the post World War II era (Meyer, 2005, 5). Conceiving of world polity as macro-sociological implies that it represents an all encompassing cultural frame of reference in which the social reality is produced and perceived. The resulting social macro-structure cannot be understood along the interactions of individuals and it is not reducible to them. The idea is that social action or customs relate directly to cognitive-cultural patterns on a world level, or as the neoinstitutionalists say, world cultural level.

In numerous empirical studies neoinstitutionalist researchers found substantial isomorphism across countries - by this they mean a surprising structural homology in several social realms, e. g. education, ecology, etc. (Boli/Thomas, 1997, 172, see also the citations there).

In the words of John W. Meyer, the world polity is understood "as a broad cultural order that has explicit origins in Western society." (Meyer, 1987, 41). In this sense, as Georg Krücken points out, the term can be closely associated with Max Weber's concept of Occidental rationalization; the latter consists of faith in rational progress, secularization, the imposition of rational action (i. e., intentional and functional) on all realms of social life. Also, other cultural patterns figure highly within world polity: individualization, universal conceptions of justice and fairness as well as world citizenship are important features of the concept and these aspects are particularly significant in the Brazilian discussion. The worldwide diffusion of these orientations as well as the corresponding structures supposed for their implementation build the object of study of this research strand (Krücken, 2005, 9).

The neoinstitutionalist perspective argues that, what constitutes society are not actors and their interests, as if in a 'bottom up' movement; on the contrary, society constitutes its own actors in a 'top down' process. What is seen as the nation-state, formal organizations, and the individual - the three central actors in the world polity perspective -is constituted in continuous rationalization processes through the diffusion of 'world polity' principles - i. e. cognitive-cultural concepts sprung from Western civilization (see Thomas et al., 1987; Meyer, 1986). To assume that these are totally autonomous actors would be however wrong; as the neoinstitutionalists point out, these actors follow a 'script' and are only legitimized insofar as they abide by the 'blueprint for action' commended by the world polity. Actors are constituted in a

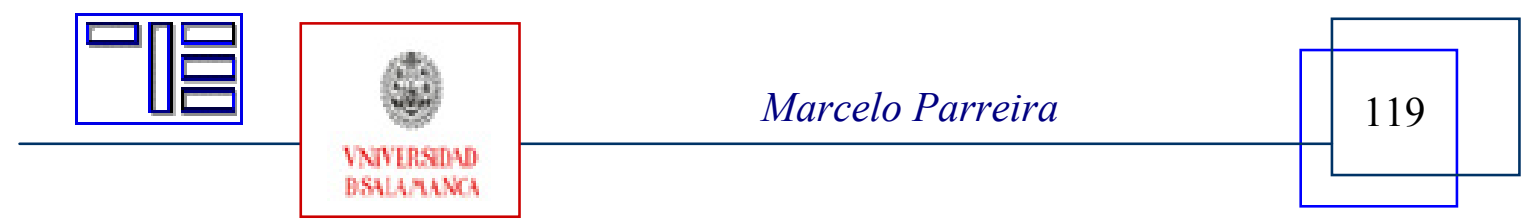


Revista Electrónica Teoría de la Educación.

Educación y Cultura en la Sociedad de la Información.

http://www.usal.es/teoriaeducacion

Vol. 9. No 2. Mayo 2008

dialectical process: "World culture define modern actors not as cultural dopes but as creative innovators who are the one and only source of change, adaptation, and restructuring in response to situational contingencies." (Boli/Thomas, 1999, 4). Meyer's comments on individualism can also be applied to the other two actor types: "The American individual [which is seen as the paramount example of individualism, MPA] is free and empowered only within this constraining scheme ... [i. e. the world polity, MPA]" (1986, 211). Formal organizations and nation-states are also viewed as legitimate only as long as they follow certain bureaucratic rules - and more recently also particular managerial concepts - in their proceedings. In the words of Boli and Thomas:

"World-polity analyses thus emphasize the importance of cultural or institutional frames. Actors are treated not as unanalyzed "givens" but as entities constructed and motivated by enveloping frames (Jepperson 1992). The nature, purposes, behavior, and meaning of actors, whether individuals, organizations, social movements, or states, are subject to redefinition and change as the frames themselves change." (1997, 172).

One observes an increase in the number of actors in the society. In historical analyses the neoinstitutionalists have shown that all three actor types have replaced other forms of organization of actorhood and today one observes their prominence in social life. Contributions from the neoinstitutionalist perspective have analyzed empirically to which extent the concepts of world polity, as mentioned above, have been incorporated in particular issue areas, esp. with respect to human rights and education, and how they touch upon the process of constitution of actors: individuals, organizations, or states. John Boli and George G. Thomas (1997) have analyzed almost 6.000 international non-governmental organizations (INGOs) and found that they are built upon world polity concepts - Principles of universalism, individualism, rational voluntaristic authority, rational progress, rational human purposes, and world citizenship are central to their structure and aims (180ff.). The conclusion of the authors is interesting: counter to traditional thinking, states do not always lead in educing social change. In some case INGOs are the leaders: "In mobilizing around and elaborating world-cultural principles, INGOs lobby, criticize, and convince states to act on those principles, at least in some sectors and with respect to some issues." (Boli/Thomas, 1997, 187). Further pieces of research focused of other types of actors and on different social areas: John W. Meyer (1986) discusses the processes of constitution and reconstruction of individuals by means of a Western social doctrine based on the myths of socialization and personality. Meyer et al. (1997) have studied the intertwining of non-governmental organizations and the United Nations in the field of ecology. In a longitudinal study they show the quantitative increase of organizations in the environmental field on the one hand and on the other the development of common understandings and assumptions about the relation of society and nature, both of which give rise to a World Environmental Regime. In 'National Interest in International Society' Martha Finnemore (1996) presents an

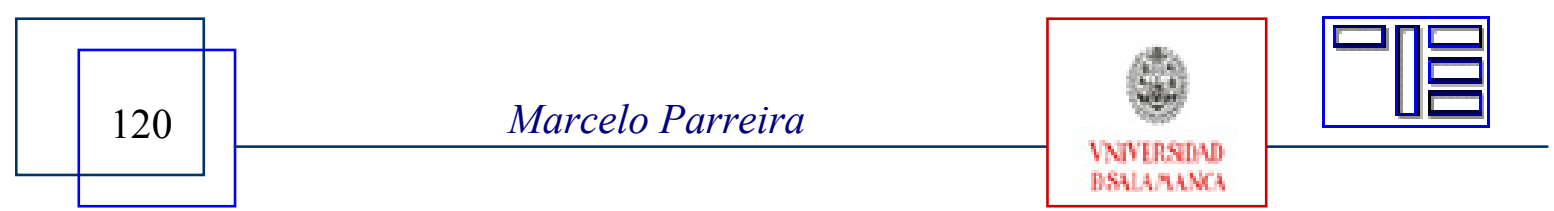


interesting case study of the influence of the international community in the development of national political preferences in the field of science policy. The active role of the UNESCO becomes visible as one of the decisive thrusts in creating national scientific bureaucracies. These studies can be seen as example of how world cultural principles shape/constitute actors and their conceptions of the social reality. As Boli and Thomas pointed out, "to an ever increasing degree, all sorts of actors learn to define themselves and their interests from the global culture and organizational structures in which they are embedded." $(1999,4)$.

As I argue in the contribution, the notions around the discussions over the introduction of quotas for Afro-descendants in Brazilian universities can be traced back to world cultural concepts. They are found in universalist/global understandings of how a modern state, the relations among its constituents, and its individuals (citizens) are to be organized. Against this background, one central argument in this article is that the organization of higher education entrance processes along quotas for certain individuals cannot be convincingly explained by internal imperatives, as the Brazilian context show: time and social context are only weak predictors in the explanation of the introduction of quotas in Brazil. On the contrary, the advancement of particular cognitive-cultural patterns by international organizations - especially by the UN - holds more explanatory leverage. Before we discuss this in more detail, some preliminary background of the discourse and of the actual implementation process of affirmative action policies for Afro-Brazilians is needed.

\section{3.- AFFIRMATIVE ACTION IN BRAZIL - AN ONGOING DEBATE.}

Brazil has a long tradition of non-discrimination on the basis of race or ethnic categories. "Since the abolition of slavery in 1888 and the inauguration of the republic in 1890, Brazilian constitutions and legislation have not discriminated on the basis of 'race' or 'color [...]'” (Fry, 2000, 87)

The national constitution of 1988, for instance, ruled that defendants accused of crimes of racial or color prejudice be denied bail and that there will be no recourse to statutes of limitations. In this sense it reflects and extends the Brazilian tradition of aracism and anti-racism and, in a more fundamental vein, the tradition of 'racial democracy'. Also important in this context is the Brazilian tradition of 'hybridization' or mixture that can be traced back to the well-known Brazilian sociologist Gilberto Freyre. The latter refers to the ideology that Brazil is made up of the miscegenation of different peoples (see also Skidmore, 1974, 38ff.) and that race or ethnic origin has not precluded from 'fraternization and vertical mobility'. As he puts it:

"From a general point of view, the formation of Brazilian society, [...] has been a process of balancing antagonisms. [...]. But predominant over these

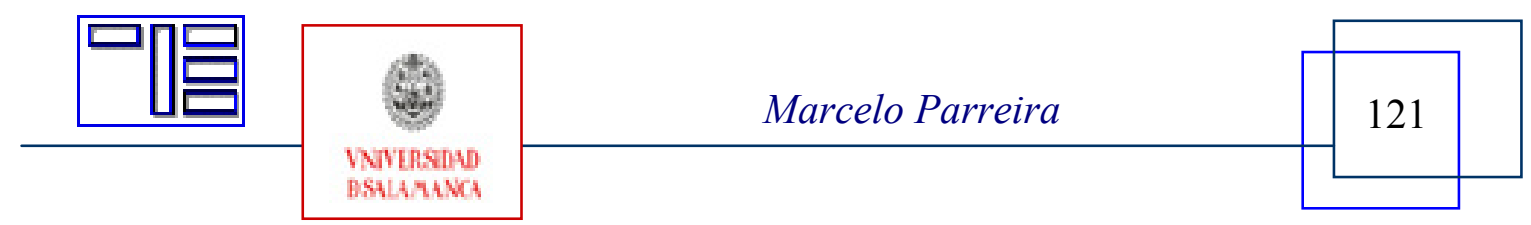


Revista Electrónica Teoría de la Educación.

Educación y Cultura en la Sociedad de la Información.

http://www.usal.es/teoriaeducacion

antagonisms was the more general and the deeper one: that between master and slave.

It is true that, acting always upon all these clashing antagonistic forces, deadening the shock or harmonizing them, have been certain conditions peculiar to Brazil that have made for fraternization and vertical mobility: miscegenation; the dispersal of inheritances; the possibility of a frequent and easy change of profession and of residence: frequent and easy access to public office and to elevated political and social positions on the part of mestizos and natural sons [...]. "(Freyre, 1946 [1933], 79f.).

Throughout most of the twentieth century the idea of mestization was part of the Brazilian imagination as a virtue, not a predicament. This idea, in turn, relates to the idealization of nation expressed by the modernist movement of the 1920s and 1930s. In the late 1940s the UNESCO financed a study of racial relations in Brazil, largely because the country was seen a viable alternative to segregation (Chor Maio, 1998). Race relations in Brazil became an often cited counter-example to the United States (Degler, 1971). In Brazil classification is not made along the dichotomous North American model - either black or white - nor according to the "one-drop rule" (descent) (cf. ibid., 101f.), but rather on the basis of a complex taxonomy of terms according to appearance: black (preto/negro), brown (pardo), mulato, yellow (amarelo), white, etc.

The imagined Brazilian 'racial democracy' clashes, however, with social reality. Racial inequities are present in Brazil and have been well documented during the past decades. Degler pointed to an important factor, when - already in the early 1970s commenting on the Brazilian Dilemma he stated "that a competitive society encourages discrimination and tension." (1971, 281). Access to education has been such a field of competition and proponents of racial quotas for higher education entrance refer to the fact that although this segment represents almost half of the population, its share in higher education is however consistently substantially lower (Hasenbalg, 1979; Andrews, 1992; Henriques, 2001).

The definition of affirmative action relates back to the most important convention of the elimination of all forms of racism adopted by the United Nations in 1965:

"Special measures taken for the sole purpose of securing adequate advancement of certain racial or ethnic groups or individuals requiring such protection as may be necessary in order to ensure such groups or individuals equal enjoyment or exercise of human rights and fundamental freedoms shall not be deemed racial discrimination, provided, however, that such measures do not, as a consequence, lead to the maintenance of separate rights for different racial groups and that they shall not be continued after the objectives for which they were taken have been achieved." (ICERD, 1965).

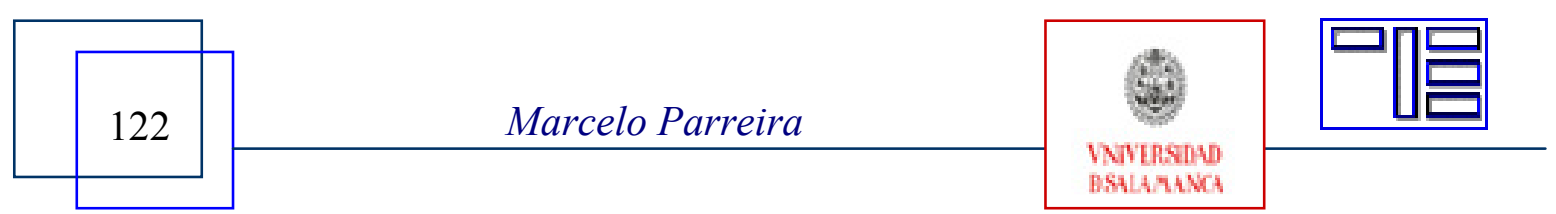


The adoption of affirmative action policies in Brazil represents, on the one hand, the national implementation of a Plan of Action accorded in the Third World Conference against Racism, Racial Discrimination, Xenophobia, and related Intolerance in Durban, South Africa in 2001 (OHCHR, 2001, 32ff.). (We return to this point below). On the other hand, and despite its recurrent association to the US-American example, affirmative action is not entirely new in Brazil and can be traced back to 1930 when, shortly after the creation of the Labor Ministry, a law called 'Two Thirds Law' was passed to guarantee employment to native Brazilians at a time when many shops were owned by recent immigrants. Moreover, in 1990 the Brazilian government passed legislation ruling that $20 \%$ of the positions in public service be reserved for disabled people; since $199730 \%$ of the candidates in elections must be women. Yet, only in 2001 has the ethnic category been used when affirmative measures targeted explicitly Afro-descendants as a group - the first to adopt such measures were the Ministry of Justice and the Federal Supreme Court; for these two there was a minimum of $20 \%$ of the positions as directors, senior consultants and others should be of Afro-Brazilian descent.

The administrations of President Lula da Silva marked a more definite departure in the direction of using the category 'race' to implement affirmative action. Besides appointing three ministers of Afro-Brazilian descent, in 2003 he set up a special secretariat for the promotion of policies for racial equality (SEPPIR - Secretaria Especial de Políticas de Promoção da Igualdade Racial). Since 2005 schools have to include information on race/color in the registration cards of their pupils. The passing of a law amending the current National Education Law of 1996 represents further important landmark in the institutionalization of the recent discourse on preferential action. The law passed included the subject 'Afro-Brazilian History and Culture' into the compulsory official curriculum for the public school system (Santos/Lobato, 2003, 12).

The federal government reserves stipends for 'blacks', 'browns, and 'indigenous people' in its scholarship program called ProUni, which grants financial aid to disadvantaged students (MEC, 2004). Moreover, the Education Ministry has also created a program for the promotion and institutionalization of affirmative action for Afro-Brazilians, especially programs and initiatives that improve their access and permanence in higher education (MEC, 2006).

The more recent public discourse over quotas for Afro-descendants in universities was triggered off by the passing by acclamation - i. e. without any debating - of a law reserving $40 \%$ of places at the two state universities in Rio de Janeiro for "blacks and browns" (ALERJ, law $n^{\circ} 3708$, from Nov. $9^{\text {th }}, 2001$ ). This percentage was added to the other $50 \%$ of places reserved for leavers of the public school system, as ruled by law $\mathrm{n}^{\circ} 3524 / 2000$, and to the $10 \%$ reserved for disabled applicants according to law $\mathrm{n}^{\circ} 4.061 / 2003$, resulting in $100 \%$ ! The original legislation (ALERJ, law $\mathrm{n}^{\circ}$ $3708 / 2001$ ) was then amended in order to harmonize with the other two laws

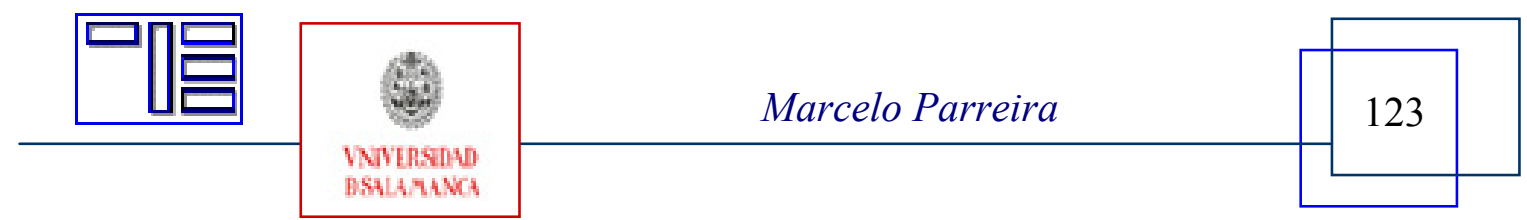


Revista Electrónica Teoría de la Educación.

Educación y Cultura en la Sociedad de la Información.

http://www.usal.es/teoriaeducacion

Vol. 9. No 2. Mayo 2008

mentioned above and in September $200445 \%$ of the places were reserved for: a) graduates from the public school system $(20 \%)$, b) 'blacks' (negros) $(20 \%)$, and c) disabled persons, members of ethnic minorities, and children of civil servants of the state of Rio de Janeiro (5\%) (cf. ALERJ, law $\mathrm{n}^{\circ}$ 4151/2003, Art. 1; Law $\mathrm{n}^{\circ}$ 5074/2007).

Several other universities in other parts of the country and on all levels - federal, state, and municipal - voluntarily adopted similar regulations. According to the Laboratório de Políticas Públicas at the University of the State of Rio de Janeiro by August 200743 higher education institutions across the country reserved quotas for Afro-Brazilians (LPP, 2007). Such legislation aroused opposition from several quarters of society. For the critics, quotas are contrary to Brazil's philosophical, cultural, and legal traditions. Issues over their constitutionality on grounds of equality, issues of merit questioning the effects on the quality of the system; arguments on the stigmatization of beneficiaries, and other more are frequent arguments of those who make a point for universalist policies. However, the interesting controversy concerns rather the implementation of affirmative action, in this case quotas for Afro-Brazilians. The argument is that its application in Brazil is not possible. Due to the high degree of miscegenation of the population it would be difficult to define who qualifies for the benefits. The categories used in the population census in Brazil - here for the year 2000 - include the category color or race (cor ou raça) which is divided in 'white' (53,74\%), 'brown' (parda) (38,45\%), 'black' (6,21\%), "yellow"' (0,45\%), and 'indigenous' (0,43\%) (cf. IBGE, 2000). The proponents of quotas argue that since blacks and browns share similar social disadvantages; in fact, law $n^{\circ} 3.708 / 2001$ originally mentioned 'blacks and browns' in its text - pointing to the fact that both segments face similar difficulties. Only against this background it is possible to argue that "blacks" made up half of the Brazilian population. However, the wording of law $n^{\circ} 4.151 / 2003$ which supplanted the previous one mentions only 'blacks' ('negros'). This led one of the most prominent critic suggest that the proponents of a bi-racial Brazil made the 'browns' (pardos) disappear (Kamel 2006). Quotas for public school leavers have also been criticized for discriminating against the many who attend private schools, mainly due to the poor quality of the public system (Hazin, 2006).

The critics of affirmative action also point to the selective use of statistical data: when mentioning the percentage of the total population proponents of affirmative action subsume 'blacks' and 'browns' into one category, yet refer only to 'blacks' when pointing to access to higher education (cf. Maggie/Fry, 2002, 74f.). Since application is based on self-description of the student (plus an attached picture) and universities have commissions that decide if the applicant is 'black' enough to qualify for the benefit, there is lot of potential for dispute on both sides - some claiming arbitrariness, others opportunism. Indeed, several cases have been reported which show the complexity of the implementation. For instance, the Brazilian magazine 'Veja' reported on identical twin brothers, Alan and Alex, who applied for a study

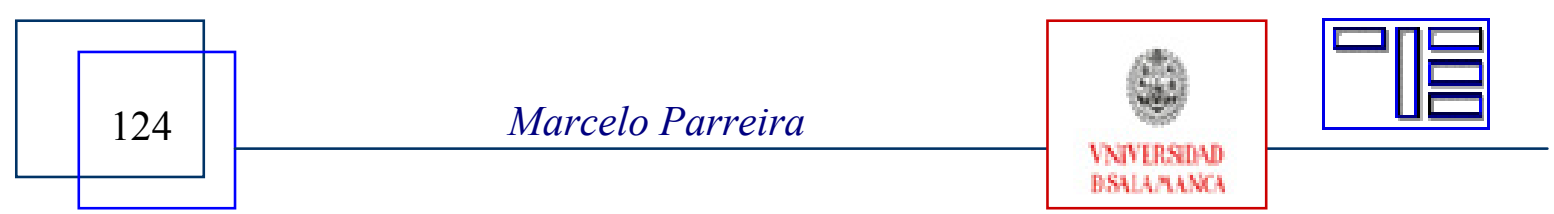


place at the University of Brasília on the basis of affirmative action; while one was found to qualify for the benefit the other was not (Revista Veja, 2007, 82). In Rio de Janeiro there have been hundreds of applications for judicial revision of decisions (see Santos, 2006, 155ff.).

The greatest challenge is though to assure that students remain in higher education. Comparing the family income of those in higher education with that of those who are not, one observes that it is 2.1 times higher (census data - PNAD 2001). Almost $70 \%$ of those in higher education have an average income of 8 times the statutory minimum wage (Nunes/Martignoni/Carvalho, 2003, 11ff.). For the majority of those gaining access to higher education on an affirmative action tickets the chance of dropping out is substantially higher since their material conditions are usually insufficient. For this reason most universities added economic criteria to the racial one for applications.

The discussion above has been largely illustrative and selective; however, it intended to point to the myriad of controversial issues raised by the introduction of affirmative action in university entrance processes in Brazil. It clashes with Brazilian traditions, both political and cultural and poses several operational problems. The following section discusses the 'world cultural' nature of this policy option and relates it to the Brazilian case.

\section{4.-DISCUSSION.}

The introduction of affirmative action in higher education entrance processes in Brazil reserving quotas for Afro-descendants cannot be convincingly explained by internal imperatives. Neither the perceived philosophic-cultural-social tradition nor the timing of the adoption can be seen as strong predictors in the explanation of the introduction of quotas there. The imagined tradition of 'racial democracy' as well as the idea of miscegenation has long had the effect of diminishing the appeal of the category race in the discussions about social equality in the country. Racial prejudice is surely present in Brazil, it is however not necessarily only associated with skin color; as empirical studies show its mechanisms are far more complex (Almeida, 2007). With respect to timing it seems rather unconvincing to see Brazil merely as a (very) late adopter of the policy. The international experience, especially the American, shows the many controversies and drawbacks of this option (Sowell, 2004). In fact, in a US-Supreme Court landmark decision (Regents of the University of California v. Bakke) quotas have been declared unconstitutional - even if not affirmative action itself - already in 1978.

On the contrary, the advancement of particular cognitive-cultural patterns by international discourses - mainly through the international organizations - seems to hold more explanatory power. The assumptions behind affirmative action relate to

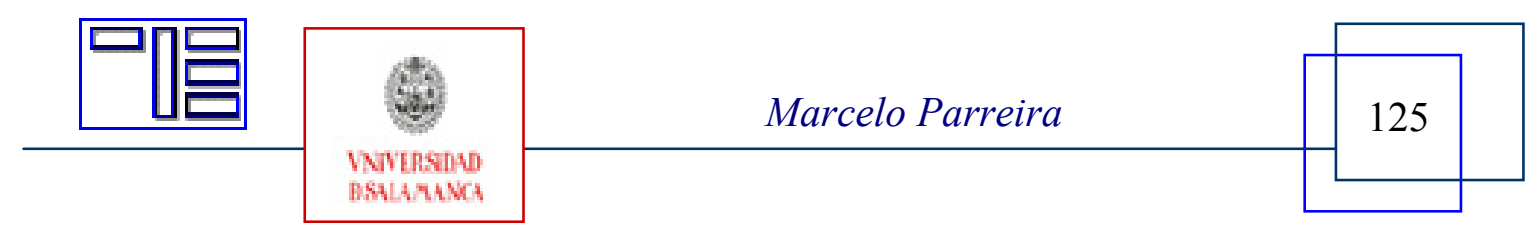


Revista Electrónica Teoría de la Educación.

Educación y Cultura en la Sociedad de la Información.

http://www.usal.es/teoriaeducacion

Vol. 9. No 2. Mayo 2008

ideas and understandings drawn from a larger cultural framework, i. e. a global culture in the neoinstitutionalist sense.

Universal human rights are part and parcel of the 'world institutional order' (Boli, 1987, 133, ital. in orig.), to which Brazil can be seen to abide, particularly after redemocratization after 1988. A key aspect - and source of controversy for the implementation of affirmative action - is the individual basis of affirmative action. Individualism is seen as a central world polity principle and all modern societies are organized in this way. Individuals are supposed to act rationally; they have rights and obligations, and so on. In respect to their rights, during the past two centuries subsequent 'waves' of rationalization have institutionalized political, economic, social, and cultural rights as inalienable to individualism. The Brazilian discussion is about economic/social and cultural rights of individuals and groups; bringing these two different claims to justice together makes the issue controversial since the one is attributed to the individual and the other to a group (of individuals). The Durban Declaration indeed recognize both individuals and groups as units in the fight against racism and discrimination (OHCHR, 2001, 5). On the one hand, quotas in Brazil have to be seen as part of a larger effort of several groups to create a collective 'Black' identity (Fry, 2000, 104). On the other hand though, it collides with the logic that quotas are for individuals. While the Brazilian approach of racial self-classification allows individuals to choose the category suitable to their identity. Applicants to university quotas have to recognize themselves as members of one group and risk not qualifying for. Here, several important issues remain unresolved in Brazil.

Brazil's embeddedness in a web of international conventions also point to the frame, in which the country is inserted and which represent the 'script' for legitimate action. Brazil is signatory of a host of agreements: the 1958 convention number 111 of the International Labor Organization which refers to the discrimination in the field of employment and occupation; the United Nations International Convention on the Elimination of all Forms of Racial Discrimination (ICERD) from 1965; or the Convention on the Elimination of All Forms of Discrimination against Women (CEDAW) adopted in 1979 by the UN General Assembly. The world polity perspective point to the influence of international organizations in diffusing particular social and cultural policies; indeed the importance of the Durban conference cannot be overestimated for the issue both before and after the event (see for example Bentes, 2002; Htun, 2004).

Furthermore, there has been a substantial increase in formal organizational activity both governmental and non-governmental - advocating the rights of Afro-Brazilians. In addition to international bodies there are also national groups: one of these is the 'Working Group for the Elimination of Discrimination in Employment and Education' (Grupo de Trabalho para Eliminação da Discriminação no Emprego e na Ocupação - GTEDEO). The group was created after a formal complaint of a labor union - Central Única dos Trabalhadores - to ILO in 1996. In 1995 after the 'Marcha

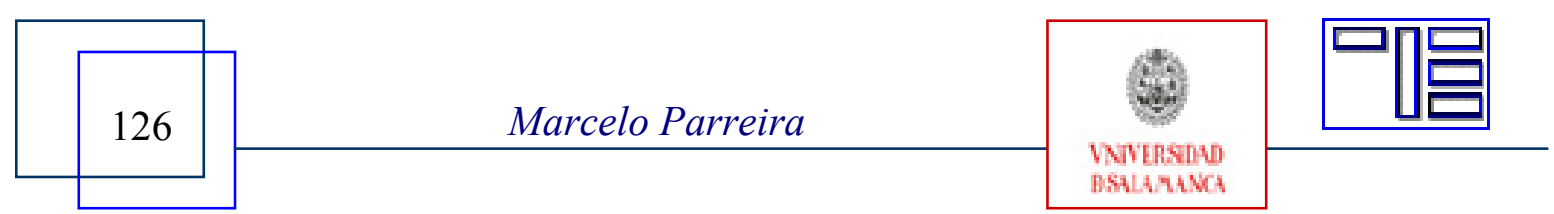


Zumbi' - this was a march in Brasília to commemorate the 300th anniversary of the black hero Zumbi (a 17th century leader of a maroon community in the Northeast region) - the government created an 'Interministerial Group for the Valorization of the Black Population' (Grupo de Trabalho Interministerial (GTI) para Valorização da População Negra). A great number of NGOs acting on this area was created, especially from the late nineteen eighties and early nineties (cf. the Brazilian association of NGOs ABONG >>http://www.abong.org.br/ $/<$ ). All these formal organizations mentioned above are core social actors, not only instruments. They have to be seen as endemic of global processes structuring social life. In Brazil one can observe the process of structuration of a relatively new social concern - a specific understanding of racial equality - in exactly the way predicted by the world polity theory: formal and organized (cf. Meyer et al., 2006) while at the same time other forms of organizing are de-legitimated.

The discussion above tells, however, only half of the story. The world polity perspective is useful in explaining how a particular policy option, here affirmative action in the North American sense, is selected by a country with quite different structures and traditions without putting too much emphasis on the rather reductionist idea of 'symbolic violence' (Bourdieu/Wacquant, 1998). The national discussions, mechanisms of implementation, and, most importantly, the different understandings of affirmative action need to receive more attention if we want to see the full picture.

The Brazilian discussion shows that while cultural issues of the groups of Afrodescent have been to some extent successfully incorporated into the mainstream debate and that a new debate has started over the significance of 'racial democracy' in the country - and this is also a pressing issue; structural issues such as the elitist nature of university examination processes (vestibular), the negative effects of the private sector in higher education, income disparity as the basis of unequal access to higher education, and many others, have not or only marginally been addressed.

\section{5.- BIBLIOGRAPHY.}

ALERJ (Assembléia Legislativa do Estado do Rio de Janeiro). (2000). Lei $3524 / 2000$, retrieved $\quad$ Oct. $19^{\text {th }}, \quad 2007$ from http://www.alerj.rj.gov.br/processo2.htm

ALERJ (Assembléia Legislativa do Estado do Rio de Janeiro). (2001). Lei $3708 / 2001$, retrieved $\quad$ Oct. $19^{\text {th }}$, 2007 from http://www.alerj.rj.gov.br/processo2.htm

ALERJ (Assembléia Legislativa do Estado do Rio de Janeiro). (2003). Lei 4061/2003, retrieved Oct. http://www.alerj.rj.gov.br/processo2.htm

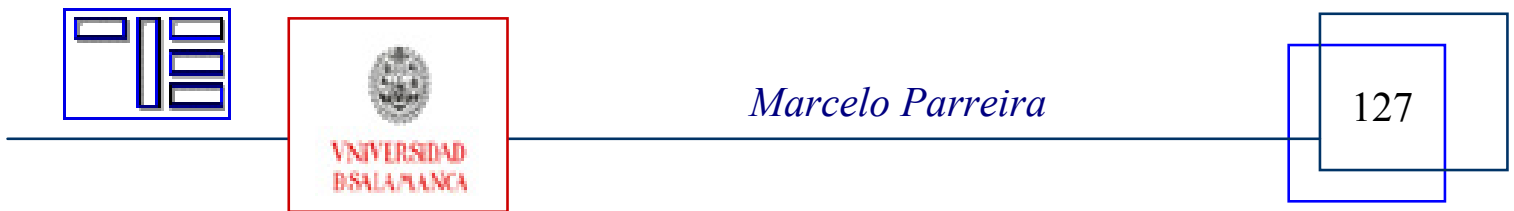


Revista Electrónica Teoría de la Educación.

Educación y Cultura en la Sociedad de la Información.

http://www.usal.es/teoriaeducacion

Vol. 9. No 2. Mayo 2008

ALERJ (Assembléia Legislativa do Estado do Rio de Janeiro). (2003). Lei 4151/2003, $\quad$ retrieved $\quad$ Oct. $19^{\text {th }}, \quad 2007$ from http://www.alerj.rj.gov.br/processo2.htm

ALERJ (Assembléia Legislativa do Estado do Rio de Janeiro). (2007). Lei 5074/2007, retrieved $\quad$ Oct. $19^{\text {th }}$, 2007 from http://www.alerj.rj.gov.br/processo2.htm

ALMEIDA, A. C. (2007). Preconceito de Cor ou Racial no Brasil. In A Cabeça do Brasileiro, (pp. 213-234). Rio de Janeiro: Editora Record.

AMOS, S. K. (2007). Das amerikanische "Urban Ghetto" als sozial-räumlicher Ausdruck prekärer gesellschaftlicher Mitgliedschaft. In Kessl, F./Otto, H.-U. (Eds.). Territorialisierung des Sozialen. Regieren über soziale Nahräume (pp. 233-253). Opladen/Farmington Hills: Barbara Budrich.

ANDREWS, G. R. (1992). Desigualdade Racial no Brasil e nos Estados Unidos: Uma Comparação Estatística". Estudos Afro-Asiáticos, 22, 47-83.

ATKINSON, R./DAVOUDI, S. (2000). The Concept of Social Exclusion in the European Union: Context, Development and Possibilities. Journal of Common Market Studies, 38 (3), 427-448.

BENTES, N. (2002). Brasil-Durban-Brasil: Um Marco da Luta contra o Racismo. Estudos Feministas, 10 (1), 229236.

BOLI, J. (1987). Human Rights or State Expansion? Cross-National Definitions of Constitutional Rights, 1870-1970. En: THOMAS, G. M. et al. (Eds.): Institutional Structure. Constituting State, Society, and the Individual. Newbury Park, Sage, 133-149.

BOLI, J./THOMAS, G. M. (1997): World Culture in the World Polity: A Century of International Non-Governmental Organization. In: American Sociological Review. Vol. 62, 171-190.

BOLI, J./THOMAS, G. M. (1999): World Polity Since 1875: World Culture and International Non-Governmental Organizations. Stanford, Stanford UP.

BOURDIEU, P. et al. (1999) (Eds.): The Weight of the World. Suffering in Contemporary Society. Cambridge, Polity Press.

BOURDIEU, P.e/WACQUANT, L. (1998): Sur les Ruses de la Raison Impérialiste. In: Actes de la Recherche en Sciences Sociales, Vol. 121-122, Nr. 1, 109-118.

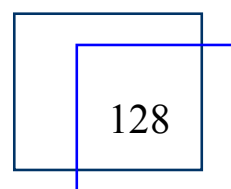

Marcelo Parreira
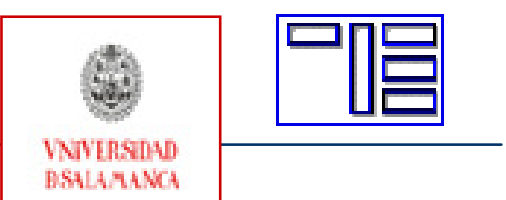
CHOR MAIO, M. (1998): O Brasil no Concerto das Nações: A Luta contra o Racismo nos Primórdios da Unesco. In: História, Ciência, Saúde-Manguinhos, Vol. 5, n. 2, 375-413.

COMMISSION OF THE EUROPEAN COMMUNITIES (1993): Social Europe. Towards a Europe of Solidarity: Combating Social Exclusion. Suppl. 4/93. Brüssel/Luxemburg.

DEGLER, C. (1971): Neither Black nor White: Slavery and Race Relations in Brazil and the United States. New York et al., Macmillan et al.

DESHPANDE, A. (2006): Affirmative Action in India. In: KENNEDYDUBOURDIEU, E. (Ed.): Race and Inequality. World Perspectives on Affirmative Action. Aldershot, Ashgate, 63-76.

FINNEMORE, M. (1996): Norms and State Structure: UNESCO Creation and the Creation of State Science Bureaucracies. In: FINNEMORE, M. National Interests in International Society. Ithaca/London, Cornell UP, 34-68.

FREYRE, G. (1933). Casa Grande e Senzala. Rio de Janeiro: Maia \& Schmidt.

FREYRE, G. (1946). The Masters and the Slaves: A Study in the Development of Brazilian Civilisation. New York: Knopf.

FRY, P. (2000). Politics, Nationality, and the Meanings of "Race" in Brazil. Daedalus, 129, 83-118

GLAZER, N. (1997). We Are all Multiculturalists Now. Cambridge, Mass.: Harvard UP.

HASENBALG, C. (1979). Discriminação e Desigualdades Raciais no Brasil. Rio de Janeiro: Graal.

HAZIN, F. (2006). O Regime de Quotas nas Universidades (Ou o Exílio do Bom Senso): Online at: $>$ http://www.ufrpe.br/artigos/artigo-33.html $<<$ [retrieved Oct. 19 $\left.9^{\text {th }}, 2007\right]$.

HENRIQUES, R. (2001). Desigualdade Racial no Brasil: Evolução das Condições de Vida na Década de 90. Discussion Paper $\mathrm{N}^{\circ}$ 807, IPEA, online at: $>$ http://www.ipea.gov.br/pub/td/2001/td_0807.pdf $<<$ [retrieved Oct. 19 ${ }^{\text {th }}, 2007$ ].

HTUN, M. (2004). From "Racial Democracy" to Affirmative Action: Changing State Policy on Race in Brazil. Latin American Research Review, 1, (1), 60-89.

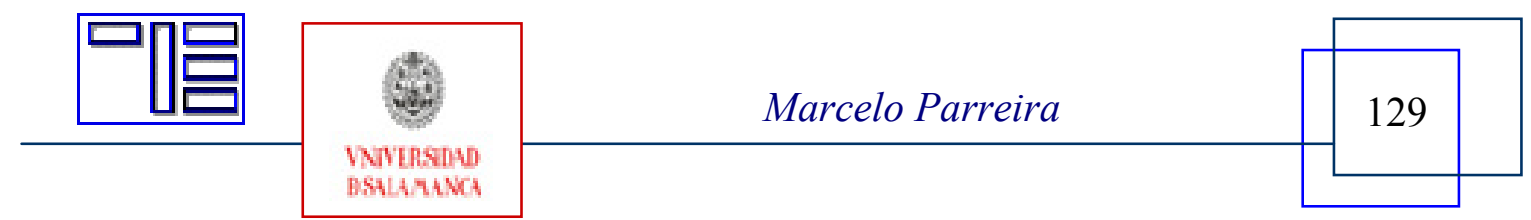


Revista Electrónica Teoría de la Educación.

Educación y Cultura en la Sociedad de la Información.

http://www.usal.es/teoriaeducacion

Vol. 9. No 2. Mayo 2008

IBGE (2007). Censo de 2000, online at: >>http://www.ibge.gov.br/home/estatistica/populacao/censo2000/default_prim_r esultados.shtm $<<$ [retrived Oct. $\left.19^{\text {th }}, 2007\right]$.

ICERD, (1965): International Convention on the Elimination of all Forms of Racial Discrimination. Online at: >>http://www.ohchr.org/english/law/pdf/cerd.pdf $<<$ [retrieved Oct. 19 ${ }^{\text {th }}, 2007$ ].

KAMEL, A. (2006): Não Somos Racistas. Rio de Janeiro, Nova Fronteira.

KRONAUER, M. (2002): Exklusion. Die Gefährdung des Sozialen im hoch entwickelten Kapitalismus. Frankfurt am Main, Campus.

KRÜCKEN, G. (2005): Introduction to: MEYER, J. W.: Weltkultur. wie die westlichen Prinzipien die Welt durchdringen. Frankfurt am Main, Suhrkamp, 716.

KRÜCKEN, G. (2006): World Polity Forschung. In: SENGE, K./HELLMANN, K.U. (Eds.): Einführung in den Neo-Institutionalismus. Wiesbaden, VS Verlag, 139-149.

LABORATÓRIO DE POLÍTICAS PÚBLICAS (LPP), (2007), universidades com Cotas, online at: $\quad>$ http://www.lppuerj.net/olped/AcoesAfirmativas/universidades_com_cotas.asp $<<$ [retrieved Oct. $\left.19^{\text {th }}, 2007\right]$.

LE MONDE DIPLOMATIQUE (Ed.) (2003). Atlas der Globalisierung. Berlin: Taz.

LUHMANN, N. (1999). Jenseits von Barbarei. En: LUHMANN, N. (Edts.): Gesellschaftsstruktur und Semantik. Studien zur Wissenssoziologie der modernen Gesellschaft, (pp.138-150). Frankfurt/M.: Suhrkamp.

LUHMANN, N. (2005). Inklusion und Exklusion. En: LUHMANN, N. (Ed.): Soziologische Aufklärung 6. Die Soziologie und der Mensch, (pp. 226-251). Wiesbaden: VS Verlag.

MAGGIE, Y./FRY, P. (2002). A Reserva de Vagas para Negros nas Universidades Brasileiras. Estudos Avançados, 1, 93-117.

MEC (Ministério da Educação), UniAfro, 2006, online at: > http://portal.mec.gov.br/sesu/arquivos/pdf/UNIAFRO/edital002.pdf $<<$ [retrieved Oct. $\left.19^{\text {th }}, 2007\right]$.

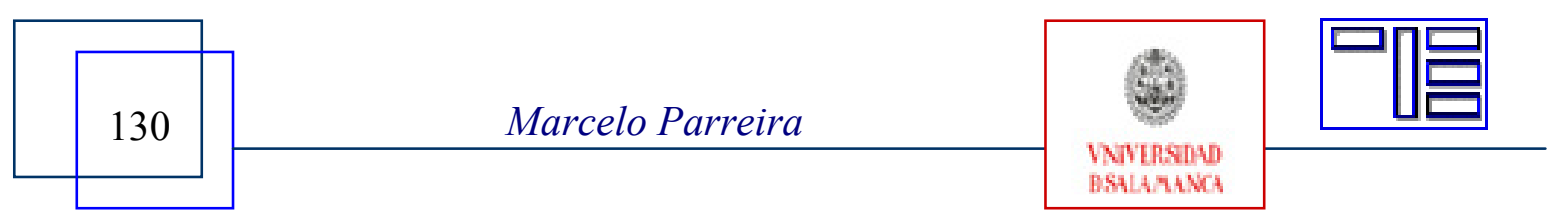


MEC (Ministério da Educação), ProUni, 2004, online at: $>$ http://www.planalto.gov.br/ccivil/ ato2004-2006/2004/mpv/213.htm $<<$ [retrieved Oct. 19 $9^{\text {th }}, 2007$ ].

MEYER, J. W. (1986). Myths of Socialization and Personality. En: HELLER, T. C. et al. (Eds.) (1986): Reconstructing Individualism. Autonomy, Individuality, and the Self in Western Thought, (pp. 208-221). Stanford: Stanford UP.

MEYER, J. W. (1987). The World Polity and the Authority of the Nation State. En: THOMAS, G. M. et al. (Eds.): Institutional Structure. Constituting State, Society, and the Individual, (pp. 41- 70). Newbury Park: Sage.

MEYER, J. W. (2005). Preface. En: HASSE, R.; KRÜCKEN, G. (Eds.): NeoInstitutionalismus, (pp. 5 -12). Bielefeld: Transcript.

MEYER, J. W./DRORI, G. S./HWANG, H. (2006). World Society and the Proliferation of Formal Organizations. En: DRORI, G. S. et al. (Eds.): Globalization and Organization. World Society and Organizational Change, (pp. 25-49). Oxford: Oxford UP.

MEYER, J. W./FRANK, D./HIRONAKA, A./SCHOFER, E./TUMA, N. (1997). The Structuring of a World Environmental Regime, 1870-1990. International Organizations, 51, 623-651.

MEYER, J. W./ROWAN, B. (1977). Institutionalized Organizations: Formal structure as Myth and Ceremony. American Journal of Sociology, Vol. 83, No 2, 340-363.

NUNES, E./MARTIGNONI, E./CARVALHO, M. M. (2003). Expansão do Ensino Superior: Restrições, Impossibilidades e Desafios Regionais. Retrieved Oct. $19^{\text {th }}$, 2007

from

http://www.observatoriouniversitario.org.br/pdf/Doctrab\%2025\%20-

$\% 20$ Expans $\%$ E3o\%20do\%20Ensino\%20Superior.pdf

OHCHR. (2001). Durban Plan of Action. Retrieved Oct. 19 th $^{\text {th }} 2007$ from http://portal.unesco.org/shs/en/files/3951/10771030361Durban_Declaration_and _Plan_of_Action.pdf/Durban\%2BDeclaration\%2Band\%2BPlan $\% 2 B o f \% 2 B \bar{A} c t i$ on.pdf

OOIMAN ROBINSON, J. A. (2006). Affirmative Action in the United States. En: KENNEDY-DUBOURDIEU, E. (Eds.): Race and Inequality. World Perspectives on Affirmative Action, (pp. 11-42). Aldershot: Ashgate.

REVISTA VEJA (2007). Especial, Edição 2011, 22 (40), 82-88.

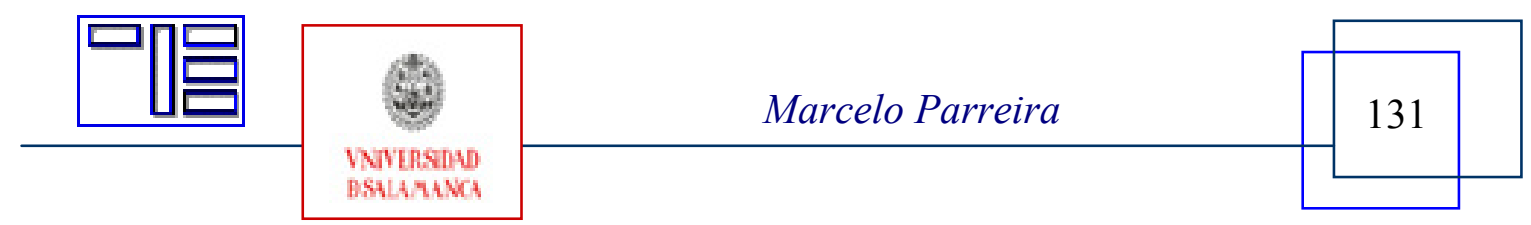


SANTOS, R. E. (2006). Política de Cotas Raciais nas Universidades Brasileiras - O Caso da UERJ. En: FERES JÚNIOR, J./ZONINSEIN, J. (Eds.): Ação Afirmativa e Universidade. Experiências Nacionais Comparadas, (pp.110-135). Brasília: Editora UnB,

SANTOS, R. E./LOBATO, F. (Eds.) (2003). Apresentação: Ações Afirmativas: Políticas Públicas contra as Desigualdades Raciais (pp. 7-12). Rio de Janeiro: DP \& A.

SKIDMORE, T. E. (1974). Black into White. Race and Nationality in Brazilian Thought. New York: Oxford UP.

SOWELL, T. (2004). Affirmative Action Around the World. An Empirical Study. New Haven, Conn: Yale UP.

THOMAS, G. M. et al. (Eds.). Institutional Structure. Constituting State, Society, and the Individual. Newbury Park: Sage.

Para citar este artículo puede utilizar la siguiente referencia:

PARREIRA DO AMARAL, Marcelo (2008). World cultural patterns: inequities in higher education and affirmative action in Brazil. En APARICIO, Pablo (Coord.) Desde la diversidad hacia la desigualdad: ¿destino inexorable de la globalización? [monográfico en línea]. Revista Electrónica Teoría de la Educación: Educación y Cultura en la Sociedad de la Información. Vol. 8, nº 2. Universidad de Salamanca. [Fecha de consulta: dd/mm/aaaa].

$<\mathrm{http}: / /$ www.usal.es/ teoriaeducacion/rev_numero_09_02/n9_02_parreira.pdf $>$ ISSN 1138-9737

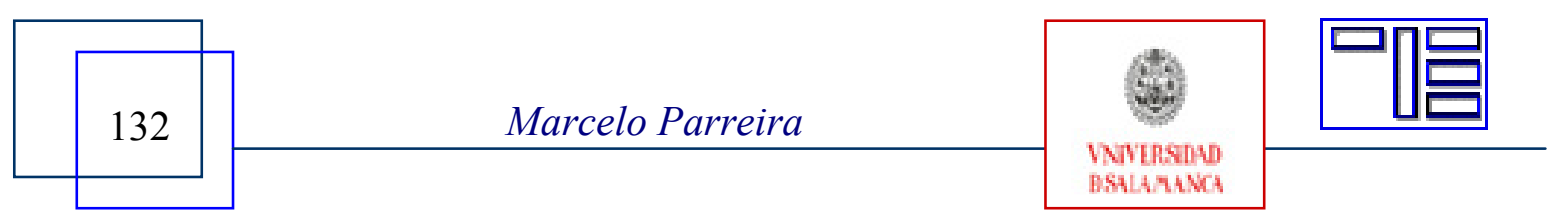

